\title{
KONSUMSI ZINC TERHADAP PENYEMBUHAN LUKA PERINEUM DAN PENURUNAN SKALA NYERI : A LITERATURE REVIEW
}

\author{
Yunisra Ikasari ${ }^{1}$, Listyaning Eko Martanti ${ }^{2}$ Sri Sumarni ${ }^{3}$ \\ 1,2, 3Jurusan Kebidanan Poltekkes Kemenkes Semarang, Indonesia
}

\begin{abstract}
Perineum wounds that occur in most childbirth need to be healed immediately to prevent infection and lower the scale of pain. Perineum wound healing is influenced by many things, one of which is zinc. The purpose of this study was to find out the effect of zinc on perineum wound healing and the relationship of perineum wound healing with decreased pain scale. The research design uses literacystudies, searches using proquest sites and google scholar. Originally found 218 articles, 186 articles were eligible after duplication checks. Articles are filtered by publication time, article type, and full text availability. The articles covered are articles published in the last 10 years (2011 and above). The types of articles discussed are articles that are not literature studies. This filtering resulted in 86 articles. Articles that are not relevant to zinc, wound healing and decreased the scale of perineum pain in eksklusi, so obtained 11 articles that became samples in the study. Zinc is able to accelerate the healing of perineum wounds. However, its effectiveness in accelerating wound healing is still less when compared to vitamin C. Zinc will be more effective in accelerating wound healing if combined with other therapies such as honey and vitamin $C$. Zinc is safe to be consumed safely by humans with a maximum limit of 40mg/day. There is a link between perineum wound healing and decreased pain scale. This research is expected to be an input for health workers, especially midwives to provide zinc tablet therapy for mothers nifas to accelerate the healing of perineum wounds.
\end{abstract}

Keywords: Zinc; Perineal Wound Healing; Pain; REEDA SCALE 


\section{PENDAHULUAN}

Masa nifas merupakan masa kritis baik ibu maupun bayinya dan diperkirakan $60 \%$ kematian ibu termasuk kehamilan terjadi setelah persalinan dan $50 \%$ kematian masa nifas terjadi dalam 24 jam setelah persalinan, salah satu komplikasi yang sering terjadi adalah ruptur perineum yang terjadi pada hampir semua persalinan primigravida dan tidak jarang pada persalinan berikutnya yang dapat menyebabkan perdarahan dan infeksi sehingga mengakibatkan terjadinya morbiditas dan mortalitas ibu (Vivian, 2015).

Ruptur/luka perineum terjadi pada hampir semua persalinan pertama dan tidak jarang juga pada persalinan berikutnya (Wiknjosastro, 2016). Luka perineum dapat mempengaruhi kesejahteraan fisik dan psikologis ibu post partum. Setiap ibu yang menjalani proses persalinan dengan luka pada perineum akan merasakan nyeri (Frohlich and Kettle, 2015).

Dampak lain dari terjadinya ruptur perineum pada ibu antara lain inkontinensia urin dan inkontinensia feses atau konstipasi, inkontinensia urin dapat mengakibatkan infeksi sistem perkemihan dan perdarahan masa nifas (Handayani \& Pujiastuti, 2016).

Menurut Nurdin (2009 dalam Ardani, 2018) Proses penyembuhan luka perineum yang normal adalah 6 sampai 7 hari postpartum. Beberapa faktor dapat mempengaruhi penyembuhan luka. zat gizi zinc berperan dalam meningkatkan proliferasi sel, proses epitelisasi dan kekuatan kolagen (Guo \& DiPietro, 2010).

Upaya yang sudah dilakukan oleh tenaga kesehatan di Puskesmas Bendan pada ibu yang mengalami luka perineum adalah memberikan pendidikan kesehatan kepada ibu nifas sebelum pulang dari Puskesmas tentang cara perawatan luka perineum, makan makanan bergizi dan tanpa pantangan. Obat yang diberikan adalah antibiotik (amoxicillin 500 mg 3x1),

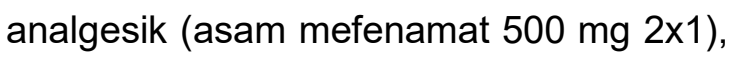
tablet Fe (Fe $250 \mathrm{mg}$, Mangan Sulfat 0,2 $\mathrm{mg}$, Tembaga Sulfat $0,2 \mathrm{mg}$, Asam Askorbat $50 \mathrm{mg}$, Asam Folat $1 \mathrm{mcg}$, Sianokobalamin $7,5 \mathrm{mg}$, Sarbitol $25 \mathrm{mg}$ ) 1x1, dan Vitamin A 2 kapsul 1x1 (200.000 $\mathrm{SI})$.

Data dari Puskesmas Bendan pada tahun 2018 jumlah persalinan dengan laserasi perineum sebanyak $340(81,53 \%)$ dan hanya $77(18,47 \%)$ yang tidak mengalami laserasi perineum. Pada tahun 2019 persalinan dengan laserasi perineum meningkat menjadi $414 \quad(88,27 \%)$ dan hanya $55(11,73 \%)$ yang tidak mengalami laserasi perineum. Data juga menunjukkan pada tahun 2018 terdapat 2 (dua) ibu post partum yang penyembuhan lukanya lebih dari 8 hari, sedangkan pada tahun 2019 ada 1 (satu) ibu post partum yang dirujuk karena mengalami hematom pada luka perineumnya. Melihat latar belakang di atas peneliti tertarik 
melakukan systematic literature review tentang pengaruh konsumsi tablet zinc terhadap penyembuhan luka perineum. Selain itu peneliti juga melakukan systematic review tentang hubungan penyembuhan luka perineum dengan penurunan skala nyeri.

\section{METODOLOGI PENELITIAN}

Penelitian ini menggunakan desain studi literatur dengan metode systematic literature review. Sumber data dalam penelitian ini adalah artikel penelitian yang didapatkan melalui pencarian menggunakan situs proquest, garuda, dan google scholar. Jumlah populasi yang ditemukan saat pencarian sebanyak 218 artikel, namun yang dibahas dalam penelitian ini sebanyak 11 artikel.

\section{HASIL PENELITIAN DAN BAHASAN}

Kata kunci pencarian adalah "zinc untuk penyembuhan luka perineum", "hubungan penyembuhan luka perineum dengan penurunan skala nyeri", "zinc on perineal wound healing" dan "perineal trauma with pain". Awalnya ditemukan 218 artikel. Ada 186 artikel yang memenuhi syarat setelah pemeriksaan duplikasi. Artikel disaring berdasarkan waktu publikasi, jenis artikel, dan ketersediaan full text. Artikel yang dibahas adalah artikel yang dipublikasikan 10 tahun terakhir (2011 ke atas). Jenis artikel yang dibahas adalah artikel yang bukan studi literatur. Penyaringan ini menghasilkan 86 artikel.

Artikel yang tidak relevan dengan zinc, penyembuhan luka dan penurunan skala nyeri perineum dieksklusi. Artikel yang dianggap tidak relevan jika membahas zinc dikaitkan dengan masalah lain seperti malnutrisi, sistem kekebalan tubuh, diare, gastritis dan keseimbangan nitrogen. Artikel juga dikatakan tidak relevan jika membahas penyembuhan luka sebagai variabel terikat namun tidak membahas zinc sebagai variabel bebas. Artikel juga dikatakan tidak relevan jika membahas penurunan skala nyeri perineum sebagai variabel terikat tapi tidak membahas luka perineum sebagai variabel bebas. Setelah beberapa artikel dieksklusi karena kriteria ini, akhirnya hanya 11 artikel yang dibahas dalam penelitian Berikut ini gambar skema penelitian : 

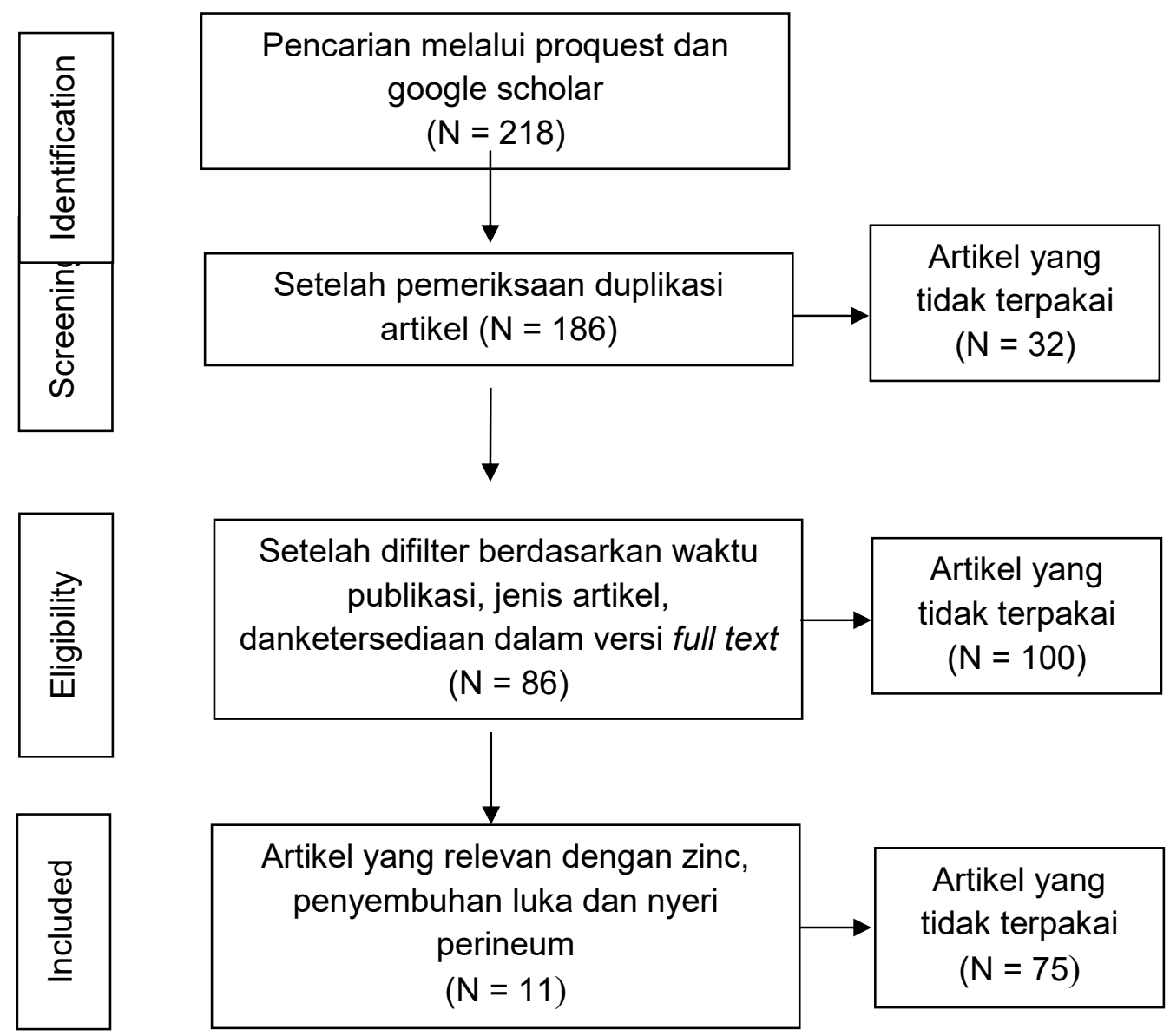

Gambar 1

Skema Penelitian

Berikut ini karakteristik artikel yang dibahas :

Tabel 1

Karakteristik Artikel Pengaruh Zinc dalam Penyembuhan Luka

\begin{tabular}{|c|c|c|c|c|}
\hline $\begin{array}{l}\text { Judul artikel } \\
\text { dan penulis }\end{array}$ & $\begin{array}{l}\text { Desain dan } \\
\text { lama studi }\end{array}$ & Populasi & $\begin{array}{l}\text { Intervensi } \\
\text { Perbandingan }\end{array}$ & Hasil Penelitian \\
\hline $\begin{array}{l}\text { The Effect of } \\
\text { Zinc and } \\
\text { Vitamin C } \\
\text { Additional on } \\
\text { Healing } \\
\text { Process of } \\
\text { Second } \\
\text { Degree } \\
\text { Perineal } \\
\text { Wound in } \\
\text { Postpartum } \\
\text { (Martanti et } \\
\text { al., 2017) }\end{array}$ & $\begin{array}{l}\text { Eksperimen } \\
\text { post test only } \\
\text { control group } \\
\text { design. } \\
\text { Selama } 7 \text { hari }\end{array}$ & $\begin{array}{l}50 \text { lbu } \\
\text { postpartum } \\
\text { dengan } \\
\text { luka } \\
\text { perineum } \\
\text { derajat II } \\
\text { di Kota } \\
\text { Semarang }\end{array}$ & $\begin{array}{l}24 \text { responden } \\
\text { diberikan Zinc } \\
\text { dengan dosis } 20 \\
\text { mg, } 1 \times 1 \text { setiap } \\
\text { hari selama } 7 \text { hari } \\
\text { dan } 26 \text { responden } \\
\text { diberikan vitamin } \\
\mathrm{C} \text { dengan dosis } \\
100 \text { mg, } 1 \times 1 \\
\text { setiap hari selama } \\
7 \text { hari }\end{array}$ & $\begin{array}{l}\text { Pada responden yang diberikan } \\
\text { vitamin C } \\
\text { Rata-rata waktu penyembuhan } \\
\text { lukanya } 8,15 \text { hari, waktu ini lebih } \\
\text { cepat dibandingkan dengan } \\
\text { responden yang diberikan Zinc yang } \\
\text { rata-rata waktu penyembuhannya } \\
9,13 \text { hari.Pada hari ke } 7 \text { jumlah } \\
\text { responden yang sembuh pada } \\
\text { responden yang diberikan Vitamin C } \\
\text { sebanyak } 16(61,5 \%) \text { lebih besar } \\
\text { dari responden yang diberikan Zinc } \\
7(29,2 \%) \text {. }\end{array}$ \\
\hline
\end{tabular}




\begin{tabular}{|c|c|c|c|c|}
\hline $\begin{array}{l}\text { Hubungan } \\
\text { Tingkat } \\
\text { Konsumsi } \\
\text { Protein, Zat } \\
\text { Besi (Fe) dan } \\
\text { Zinc (Zn) } \\
\text { dengan } \\
\text { Kondisi } \\
\text { Penyembuhan } \\
\text { Luka } \\
\text { Perineum } \\
\text { Derajat II } \\
\text { pada Ibu Nifas } \\
\text { (Aziz, } \\
\text { Soemardini } \\
\text { and Nugroho, } \\
\text { 2016) }\end{array}$ & $\begin{array}{l}\text { Analitik } \\
\text { observasional } \\
\text { dengan } \\
\text { pendekatan } \\
\text { cross } \\
\text { sectional. } \\
\text { Waktu } \\
\text { penelitian } 7 \\
\text { hari. }\end{array}$ & $\begin{array}{l}30 \\
\text { responden } \\
\text { ibu nifas } \\
\text { yang } \\
\text { mengalami } \\
\text { luka } \\
\text { perineum } \\
\text { derajat II } \\
\text { karena } \\
\text { episiotomi }\end{array}$ & - & $\begin{array}{l}\text { tingkat konsumsi protein } \\
\text { berpengaruh terhadap kondisi } \\
\text { penyembuhan luka perineum derajat } \\
\text { II ( } p=0,008) \text {, tingkat konsumsi zat } \\
\text { besi tidak memiliki pengaruh } \\
\text { terhadap kondisi penyembuhan luka } \\
\text { perineum derajat II ( } p=0,518) \text {. Hasil } \\
\text { uji chi square tingkat konsumsi zinc } \\
(p=0,278 \text { ) menunjukkan tidak ada } \\
\text { hubungan yang signifikan tingkat } \\
\text { konsumsi zinc dengan kondisi } \\
\text { penyembuhan luka. }\end{array}$ \\
\hline $\begin{array}{l}\text { Pengaruh } \\
\text { Suplementasi } \\
\text { Zinc terhadap } \\
\text { Waktu } \\
\text { Penyembuhan } \\
\text { Luka } \\
\text { Perineum } \\
\text { pada Ibu Nifas } \\
\text { (Jamhariyah, } \\
\text { 2017) }\end{array}$ & $\begin{array}{l}\text { Quasi } \\
\text { experimentalC } \\
\text { ontrol group } \\
\text { post-test only } \\
\text { selama } 7 \text { hari }\end{array}$ & $\begin{array}{l}26 \text { ibu } \\
\text { bersalin } \\
\text { yang } \\
\text { mengalami } \\
\text { Ruptur } \\
\text { Perineum }\end{array}$ & $\begin{array}{l}13 \text { responden } \\
\text { mendapatkan } \\
\text { suplementasi zinc. } \\
13 \text { responden } \\
\text { tidak } \\
\text { mendapatkan } \\
\text { suplementasi zinc }\end{array}$ & $\begin{array}{l}\text { Rata-rata waktu penyembuhan luka } \\
\text { perineum yang diberikan zinc adalah } \\
5,85 \text { hari. } \\
\text { rata-rata waktu penyembuhan luka } \\
\text { perineum yang tidak diberikan zinc } \\
\text { adalah } 7,38 \text { hari. Terdapat pengaruh } \\
\text { suplementasi zinc terhadap waktu } \\
\text { penyembuhan luka perineum. }\end{array}$ \\
\hline $\begin{array}{l}\text { Effects of } \\
\text { L-Carnosine } \\
\text { and Its Zinc } \\
\text { Complex } \\
\text { (Polaprezinc) } \\
\text { on Pressure } \\
\text { Ulcer Healing } \\
\text { (Sakae et al., } \\
\text { 2013). }\end{array}$ & $\begin{array}{l}\text { nonrandomize } \\
\text { d controlled } \\
\text { trial dengan } \\
\text { waktu } \\
\text { penelitian } \\
\text { maksimal } 4 \\
\text { minggu. } \\
\text { Keparahan/de } \\
\text { rajat ulkus } \\
\text { tekan diukur } \\
\text { setiap minggu } \\
\text { menggunakan } \\
\text { skor Pressure } \\
\text { Ulcer Scale } \\
\text { for Healing } \\
\text { (PUSH). }\end{array}$ & $\begin{array}{l}42 \text { dua } \\
\text { pasien } \\
\text { dengan } \\
\text { ulkus } \\
\text { tekanan } \\
\text { derajat II- } \\
\text { IV }\end{array}$ & $\begin{array}{l}\text { Sampel dibagi } \\
\text { menjadi } 3 \\
\text { kelompok, yaitu } \\
\text { kelompok kontrol } \\
(\mathrm{n}=14) \text { tidak } \\
\text { diobati, kelompok } \\
\text { yang diberikan } \\
\text { Zinc Complex ( } \mathrm{n}= \\
\text { 10) secara oral } \\
\text { dan kelompok } \\
\text { yang diberikan L- } \\
\text { Carnosine } 116 \mathrm{mg} \\
\text { secara oral }(\mathrm{n}= \\
\text { 18). }\end{array}$ & $\begin{array}{l}\text { Setelah } 4 \text { minggu rata-rata } \\
\text { peningkatan } \mathrm{PUSH} \text { pada kelompok } \\
\text { L-Carnosine }(1,6 \pm 0,2, \mathrm{P}=0,02) \text {, } \\
\text { kelompok Zinc Complex }(1,8 \pm 0,2 \\
\mathrm{P}=0,009) \text { dan kelompok kontrol } \\
(0,8 \pm 0,2) \text {. Tidak ada perbedaan } \\
\text { peningkatan } \mathrm{PUSH} \text { yang signifikan } \\
\text { antara kelompok } \mathrm{L}-\text { Carnosine dan } \\
\text { Zinc Complex }(P=0,73)\end{array}$ \\
\hline $\begin{array}{l}\text { Evaluate the } \\
\text { effects of } \\
\text { platelet rich } \\
\text { plasma (PRP) } \\
\text { and zinc oxide } \\
\text { ointment on } \\
\text { skin wound } \\
\text { healing } \\
\text { (Abdullah, } \\
\text { Atasoy and } \\
\text { Omer, 2019) }\end{array}$ & $\begin{array}{l}\text { Eksperimen } \\
\text { selama } 15 \\
\text { hari }\end{array}$ & $\begin{array}{l}24 \text { Kelinci } \\
\text { putih New } \\
\text { Zealand, } \\
\text { beratnya } \\
\text { sekitar } \\
1,00-1,5 \\
\text { kg dengan } \\
\text { rata-rata } \\
\text { umur } 8 \\
\text { minggu }\end{array}$ & $\begin{array}{l}\text { dibagi secara } \\
\text { acak menjadi dua } \\
\text { kelompok } \\
\text { masing-masing } \\
\text { kelompok berisi } \\
12 \text { hewan. } \\
\text { Kelompok } \\
\text { pertama diberikan } \\
\text { platelet rich } \\
\text { plasma (PRP), } \\
\text { kelompok kedua } \\
\text { diberikan zinc }\end{array}$ & $\begin{array}{l}\text { waktu penyembuhan luka kelompok } \\
\text { PRP lebih pendek dari pada terapi } \\
\text { zinc oxide dengan nilai } p \text { hari ketiga } \\
=0.007, p \text { hari ketujuh }=0.0002 \text { and } p \\
\text { hari ke limabelas }=0.002\end{array}$ \\
\hline
\end{tabular}


oxide

\begin{tabular}{|c|c|c|c|c|}
\hline $\begin{array}{l}\text { The Effects of } \\
\text { Supplemental } \\
\text { Zinc and } \\
\text { Honey on } \\
\text { Wound } \\
\text { Healing in } \\
\text { Rats (Sazegar } \\
\text { et al., 2011) }\end{array}$ & $\begin{array}{l}\text { Eksperimen } \\
\text { selama } 3 \\
\text { minggu }\end{array}$ & $\begin{array}{l}172 \text { tikus } \\
\text { muda } \\
\text { dibuat luka } \\
4 \mathrm{~cm}^{2} \\
\text { diukur } \\
\text { setiap } 2 \\
\text { hari. }\end{array}$ & $\begin{array}{l}\text { Sampel dibagi } \\
\text { menjadi empat } \\
\text { kelompok: kontrol, } \\
\text { suplemen Zn, } \\
\text { madu, Zn dan } \\
\text { madu. }\end{array}$ & $\begin{array}{l}\text { Hasil dari penelitian ini menunjukkan } \\
\text { bahwa Zn dan madu alami } \\
\text { (diberikan secara topikal) dapat } \\
\text { mempengaruhi penyembuhan luka }\end{array}$ \\
\hline $\begin{array}{l}\text { Zinc lon } \\
\text { Coordinated } \\
\text { Poly(lonic } \\
\text { Liquid) } \\
\text { Antimicrobial } \\
\text { Membranes } \\
\text { for }\end{array}$ & $\begin{array}{l}\text { Eksperimen } \\
\text { selama } 14 \\
\text { hari }\end{array}$ & $\begin{array}{l}38 \text { tikus } \\
\text { berumur } 6 \\
\text { sampai } 8 \\
\text { minggu }\end{array}$ & $\begin{array}{l}\text { Sampel dibagi } \\
\text { menjadi } 4 \\
\text { kelompok : } \\
\text { kelompok kontrol, } \\
\text { MRSA, PIL-Qa-C1 } \\
\text { dan PIL-Im-C4-Zn } \\
\text { membranes }\end{array}$ & $\begin{array}{l}\text { Dibandingkan dengan PIL Membran } \\
\text { murni, membran PIL yang } \\
\text { mengandung Zn menunjukkan } \\
\text { aktivitas antibakteri lebih tinggi. }\end{array}$ \\
\hline
\end{tabular}

Wound

Healing (Xu et al., 2017)

\begin{tabular}{|c|c|c|c|c|}
\hline $\begin{array}{l}\text { Identifikasi } \\
\text { Leptin pada } \\
\text { Kesembuhan } \\
\text { Luka Tikus } \\
\text { yang Diberi } \\
\text { Pakan Lemak } \\
\text { Tinggi dan } \\
\text { Aplikasi Zinc } \\
\text { Topikal } \\
\text { (Anggraeni, } \\
\text { Adji and } \\
\text { Sutrisno, } \\
\text { 2012) }\end{array}$ & $\begin{array}{l}\text { Eksperimen } \\
\text { selama } 3 \text { hari }\end{array}$ & $\begin{array}{l}32 \text { ekor } \\
\text { tikus } \\
\text { Sprague } \\
\text { Dawley } \\
\text { jantan } \\
\text { berumur } \\
\text { tiga bulan } \\
\text { (150-200 } \\
\text { g). }\end{array}$ & $\begin{array}{l}\text { Tikus dibagi } \\
\text { secara acak } \\
\text { menjadi empat } \\
\text { kelompok, } \\
\text { masing-masing } \\
\text { terdiri dari } \\
\text { delapan ekor. } \\
\text { Kelompok A dan } \\
\text { B diberi pakan } \\
\text { normal, } \\
\text { sedangkan } \\
\text { kelompok C dan D } \\
\text { diberi pakan } \\
\text { lemak tinggi. } \\
\text { Setelah dua bulan } \\
\text { perlakuan pakan, } \\
\text { dibuat luka irisan } \\
\text { pada kulit, } \\
\text { Kemudian dljahit. } \\
\text { Kelompok A dan } \\
\text { C, diberi vaseline } \\
\text { topikal (tanpa } \\
\text { zinc), sedangkan } \\
\text { pada kelompok B } \\
\text { dan D diberi } \\
\text { topikal zinc } 10 \% \text {. }\end{array}$ & $\begin{array}{l}\text { Analisishistopatologi pada hari } \\
\text { ketiga setelah operasi, epidermis } \\
\text { sudah menutup pada kelompok A } \\
\text { sebanyak } 75 \% \text {, kelompok B } \\
\text { sebanyak } 100 \% \text {, kelompok C } \\
\text { sebanyak } 25 \% \text {, dan kelompok D } \\
\text { sebanyak } 75 \% \text {. Dengandemikian } \\
\text { aplikasi topikal zinc dapat } \\
\text { memberikan efek positif pada } \\
\text { kesembuhan luka tikus yang diberi } \\
\text { pakan normal maupun lemak tinggi. }\end{array}$ \\
\hline $\begin{array}{l}\text { Evaluation of } \\
\text { the Effects of } \\
\text { Topical Zinc } \\
\text { Gluconate in } \\
\text { Wound } \\
\text { Healing } \\
\text { (Kaufman et }\end{array}$ & $\begin{array}{l}\text { Eksperimen } \\
\text { selama } 21 \\
\text { hari }\end{array}$ & $\begin{array}{l}98 \text { tikus } \\
\text { wistar } \\
\text { jantan } \\
\text { dengan } \\
\text { berat } 200- \\
300 \text { gram }\end{array}$ & $\begin{array}{l}\text { Sampel dibagi } \\
\text { menjadi } 7 \\
\text { kelompok : zinc } \\
\text { gluconate in } \\
\text { carrier solution, } \\
\text { carrier solution, }\end{array}$ & $\begin{array}{l}\text { Luka yang diobati dengan zinc } \\
\text { glukonat sembuh dan mengandung } \\
\text { jumlah bakteri yang sama } \\
\text { seperti luka dengan perawatan }\end{array}$ \\
\hline
\end{tabular}




\begin{tabular}{|c|c|c|c|c|}
\hline al., 2014) & & & $\begin{array}{l}\text { saline }(0.9 \% \\
\text { NaCl) solution, } \\
\text { chlorhexidine, } \\
\text { chlorhexidinepzinc } \\
\text { gluconate, } \\
\text { corticosteroid, dan } \\
\text { kontrol (tanpa } \\
\text { perlakuan). }\end{array}$ & topikal lain kecuali kortikosteroid. \\
\hline $\begin{array}{l}\text { Pengaruh } \\
\text { derajat } \\
\text { robekan } \\
\text { perineum } \\
\text { terhadap } \\
\text { skala nyeri } \\
\text { perineum } \\
\text { pada ibu nifas } \\
\text { di Kabupaten } \\
\text { Wonogiri } \\
\text { (Mulati and } \\
\text { Susilowati, } \\
\text { 2018) }\end{array}$ & $\begin{array}{l}\text { Penelitian } \\
\text { analistik }\end{array}$ & $\begin{array}{l}\text { Ibu nifas } \\
\text { yang } \\
\text { mengalami } \\
\text { laserasi } \\
\text { perineum } \\
\text { tapi yang } \\
\text { tidak ada } \\
\text { kompikasi } \\
\text { sejumlah } \\
59 \text { orang. }\end{array}$ & - & $\begin{array}{l}\text { tidak ada pengaruh yang signifikan } \\
\text { antara derajat robekan perineum } \\
\text { dengan skala nyeri perineum ibu } \\
\text { nifas dengan } \rho \text { value }=0,06(>0,05) \text {. }\end{array}$ \\
\hline $\begin{array}{l}\text { Association } \\
\text { between } \\
\text { perineal } \\
\text { trauma }\end{array}$ & $\begin{array}{l}\text { Cross } \\
\text { sectional }\end{array}$ & $\begin{array}{l}473 \text { ibu } \\
\text { nifas } \\
\text { primipara }\end{array}$ & - & $\begin{array}{l}\text { Terdapat Hubungan antara trauma } \\
\text { perineum dengan nyeri. Wanita } \\
\text { trauma perineum hampir tiga kali } \\
\text { lebih mungkin }\end{array}$ \\
\hline $\begin{array}{l}\text { and pain in } \\
\text { primiparous } \\
\text { women } \\
\text { (Francisco et } \\
\text { al., 2014) }\end{array}$ & & & & $\begin{array}{l}\text { memiliki rasa sakit daripada mereka } \\
\text { yang memiliki perineum utuh. }\end{array}$ \\
\hline
\end{tabular}

\section{Deskripsi Karakteristik Responden}

Artikel yang dibahas dalam penelitian ini tidak semuanya membahas ibu nifas dengan luka perineum sebagai responden. Artikel yang membahas ibu nifas dengan luka perineum sebagai responden adalah artikel Martanti et al., (2017), Aziz, Soemardini dan Nugroho (2016), Jamhariyah (2017), Mulati dan Susilowati (2018), serta artikel Francisco et al., (2014). Jumlah ibu yang mengalami luka perineum dalam penelitian ini sebanyak 560 orang. Penelitian Aziz,
Soemardini dan Nugroho (2016) tidak membahas karakteristik responden.

Artikel yang membahas karakteristik responden berdasarkan umur adalah artikel Martanti et al., (2017), Jamhariyah (2017), Mulati dan Susilowati (2018), serta artikel Francisco et al., (2014). Penelitian Martanti et al., (2017) menganalisa data umur responden dengan tendensi sentral, hasilnya rata-rata umur responden adalah 28,25 tahun pada kelompok zinc dan 29 tahun pada kelompok vitamin $\mathrm{C}$. Penelitian Francisco et al., (2014) juga menganalisa data umur responden dengan tendensi sentral, hasilnya rata- 
rata umur responden adalah 22 tahun.

Distribusi frekuensi responden

berdasarkan umur pada penelitian

Jamhariyah (2017) sebanyak 31\% responden berumur $<20$ tahun dan $69 \%$ responden berumur 20-35 tahun. Pada artikel Mulati dan Susilowati (2018) sebanyak $8,5 \%$ responden berumur $<20$ tahun, $88,1 \%$ responden berumur $20-35$ tahun dan $3,4 \%$ responden berumur $>35$ tahun.

Penelitian Jamhariyah (2017) serta Mulati dan Susilowati (2018) membahas karakteristik responden berdasarkan paritas. Pada penelitian Jamhariyah (2017) sebanyak 50\% responden mempunyai status primipara, $35 \%$ responden mempunyai status multipara dan $15 \%$ responden mempunyai status nulipara. Sementara pada penelitian Mulati dan Susilowati (2018) sebanyak $42,4 \%$ responden mempunyai status primipara dan $57,6 \%$ responden mempunyai status multipara.

\section{PEMBAHASAN}

Pengaruh Zinc Terhadap Penyembuhan Luka Perineum

Zinc merupakan mikronutrien esensial $(<50 \mathrm{mg} / \mathrm{kg}$ berat badan) yang dibutuhkan oleh tubuh manusia karena memiliki banyak manfaat. Zinc memiliki peranan penting untuk kesehatan manusia dan penyakit karena perannya yang vital dalam pertumbuhan dan perkembangan, metabolisme tulang, sistem saraf pusat, fungsi kekebalan tubuh dan penyembuhan luka. Zinc adalah kofaktor vital untuk fungsi lebih dari $10 \%$ protein bergantung pada zinc. Protein-protein ini memainkan banyak peran yang sangat diperlukan selsel, seperti regulasi transkripsi, perbaikan DNA, apoptosis pemrosesan metabolik, regulasi matriks ekstraseluler (ECM) dan pertahanan antioksidan. Efek patologis defisiensi zinc antara lain lesi kulit, retardasi pertumbuhan, gangguan fungsi kekebalan tubuh dan gangguan penyembuhan luka (Lin et al., 2018).

Ruptur/luka perineum merupakan masalah yang sering dialami oleh ibu nifas. Berdasarkan penelusuran peneliti ada beberapa penelitian yang berusaha membuktikan pengaruh zinc dalam penyembuhan luka perineum. Jamhariyah (2017) melakukan penelitian eksperimen terhadap 26 ibu bersalin yang mengalami ruptur perineum. 13 responden mendapatkan suplementasi zinc 1 tablet (20 mg) per hari selama 7 hari. dan 13 responden tidak mendapatkan suplementasi zinc. rata-rata waktu penyembuhan luka perineum yang diberikan zinc adalah 5,85 hari, sedangkan pada responden yang tidak mendapatkan suplementasi zinc adalah 7,38. Hasil uji t-test independent menunjukkan terdapat pengaruh suplementasi zinc terhadap waktu penyembuhan luka perineum dengan $\rho$ value $0,000(<0,05)$.

Beberapa penelitian mengkombinasikan zinc dengan terapi 
atau nutrisi lain dalam penyembuhan luka.

Aziz, Soemardini \& Nugroho (2016) melakukan penelitian analitik observasional dengan cross sectional untuk mengetahui hubungan tingkat konsumsi protein, zat besi (Fe) dan zinc $(\mathrm{Zn})$ dengan kondisi penyembuhan luka perineum derajat II. Hasil analisa regresi logistik menunjukkan tingkat konsumsi protein memberikan pengaruh yang signifikan terhadap kondisi penyembuhan luka perineum derajat II $(\rho=0,008)$. Sementara tingkat konsumsi zat besi tidak memberikan pengaruh yang signifikan terhadap kondisi penyembuhan luka perineum derajat II $(\rho=0,518)$. Untuk tingkat konsumsi zinc tidak dapat dianalisis karena hasil yang didapatkan konstan (semua responden tingkat konsumsi zincnya kurang).

Penelitian yang membandingkan keefektivan vitamin $\mathrm{C}$ dengan zinc dalam penyembuhan luka perineum pernah dilakuakan oleh Martanti et al., (2017) dengan desain eksperimen post test only control group design selama 7 hari untuk mengetahui efek pemberian zinc dan vitamin C terhadap penyembuhan luka perineum derajat II. Responden dalam penelitian ini adalah $50 \mathrm{lbu}$ postpartum dengan luka perineum derajat II. 24 responden diberikan Zinc dengan dosis 20 $\mathrm{mg}, 1 \times 1$ setiap hari selama 7 hari dan 26 responden diberikan vitamin $C$ dengan dosis $100 \mathrm{mg}, 1 \times 1$ setiap hari selama 7 hari. Pada responden yang diberikan vitamin C Rata-rata waktu penyembuhan lukanya 8,15 hari, waktu ini lebih cepat dibandingkan dengan responden yang diberikan Zinc yang rata-rata waktu penyembuhannya 9,13 hari. Pada hari ke 7 penelitian jumlah responden yang sembuh pada responden yang diberikan Vitamin C sebanyak 16 (61,5\%) lebih besar dari responden yang diberikan Zinc $7(29,2 \%)$.

Sakae et al., (2013) melakukan nonrandomized controlled trial dengan waktu penelitian maksimal 4 minggu untuk mengetahui efek L-Carnosine dan Zinc Complex (Polaprezinc) terhadap penyembuhan ulkus tekan. Keparahan/derajat ulkus tekan diukur setiap minggu menggunakan skor Pressure Ulcer Scale for Healing (PUSH). 42 dua pasien dengan ulkus tekanan derajat II-IV. Sampel dibagi menjadi 3 kelompok, yaitu kelompok kontrol $(n=14)$ tidak diobati, kelompok yang diberikan Zinc Complex (Polaprezinc), $(n=10)$ secara oral dan kelompok yang diberikan L-Carnosine $116 \mathrm{mg}$ secara oral $(n=18)$. Pada awal, tidak ada perbedaan signifikan derajat ulkus tekan pada masing-masing kelompok. Tingkat penyembuhan ulkus tekan, dinilai dengan peningkatan ratarata skor PUSH per minggu. Setelah 4 minggu rata-rata peningkatan $\mathrm{PUSH}$ pada kelompok L-Carnosine $(1,6 \pm 0,2, P=$ 0,02), kelompok Zinc Complex (1,8 \pm 0,2, $\mathrm{P}=0,009)$ dan kelompok kontrol $(0,8 \pm$ 0,2). Tidak perbedaan peningkatan $\mathrm{PUSH}$ yang signifikan antara kelompok LCarnosine dan Zinc Complex $(P=0,73)$. 
Peneliti juga menemukan beberapa artikel terkait zinc dalam penyembuhan luka dengan sampel non manusia. Salah satunya penelitian tentang evaluasi efek platelet rich plasma (PRP) dan zinc oxide ointment terhadap penyembuhan luka. Desain penelitian ini adalah eksperimen selama 15 hari sampel penelitian yang digunakan adalah 24 kelinci putih New Zealand dengan berat sekitar $1,0-1,5 \mathrm{~kg}$ yang berumur 8 minggu dibagi secara acak menjadi dua kelompok, masingmasing kelompok berisi 12 kelinci. Kelompok pertama diberikan PRP, kelompok kedua diberikan zinc oxide. Hasil penelitian menunjukkan waktu penyembuhan luka kelompok PRP lebih pendek dari pada terapi zinc oxide dengan nilai $\rho$ hari ketiga $=0,007, \rho$ hari ketujuh $=0,0002$ dan $\rho$ hari ke limabelas=0,002 (Abdullah, Atasoy and Omer, 2019).

Sazegar et al., (2011) melakukan penelitian yang bertujuan untuk mengetahui efek suplementasi zinc dan madu terhadap penyembuhan luka tikus. Desain penelitian ini adalah eksperimen selama 3 minggu dengan sampel 172 tikus muda yang dibuat luka $4 \mathrm{~cm}^{2}$ diukur setiap 2 hari. Sampel dibagi menjadi empat kelompok yaitu kontrol, suplemen zinc, suplemen madu, dan kombinasi suplemen zinc dan madu. Hasil dari penelitian ini menunjukkan bahwa zinc dan madu alami (diberikan secara topikal) dapat mempengaruhi penyembuhan luka.
$\mathrm{Xu}$ et al., (2017) melakukan penelitian eksperimen tentang koordinasi ion zinc membran antimikroba poly ionic liquid (PIL) untuk penyembuhan luka. Sampel yang digunakan adalah 38 tikus berumur 6 sampai 8 minggu yang dibagi menjadi 4 kelompok : kelompok kontrol, MRSA, PIL-Qa-C1 dan PIL-Im-C4-Zn membranes. Hasil penelitian menunjukkan membran PIL yang mengandung $\mathrm{Zn}$ menunjukkan aktivitas antibakteri lebih tinggi dibandingkan dengan PIL Membran murni.

Anggraeni, Adji and Sutrisno (2012) melakukan penelitian untuk mengetahui peran leptin pada kesembuhan luka dalam kondisi berat badan berlebih akibat pakan lemak tinggi dan keterkaitannya dengan zinc yang berperan dalam produksi leptin. Sampel penelitian adalah 32 ekor tikus yang dibagi secara acak menjadi empat kelompok ( $\mathrm{A}, \mathrm{B}, \mathrm{C}$, dan $\mathrm{D})$, masingmasing terdiri dari delapan ekor. Kelompok A dan B diberi pakan normal, sedangkan kelompok C dan D diberi pakan lemak tinggi. Setelah dua bulan perlakuan pakan, seluruh tikus dioperasi untuk membuat luka irisan pada kulit, kemudian luka ditutup dengan jahitan. Pada kelompok A dan C, luka jahitan diberi aplikasi topikal vaseline (tanpa zinc), sedangkan pada kelompok B dan D, luka jahitan diberi aplikasi topikal zinc $10 \%$. Hasil analisis histopatologi pada hari ketiga setelah operasi, epidermis sudah menutup pada kelompok A sebanyak $75 \%$, kelompok B sebanyak 100\%, 
kelompok $\mathrm{C}$ sebanyak $25 \%$, dan kelompok D sebanyak $75 \%$. Dengan demikian aplikasi topikal zinc dapat memberikan efek positif pada kesembuhan luka tikus yang diberi pakan normal maupun lemak tinggi.

Kaufman et al., (2014) melakukan evaluasi efek pemberian zinc glukonat secara topikal dalam penyembuhan luka selama 21 hari. Sampel penelitian ini 98 tikus wistar jantan dengan berat 200-300 gram yang dibagi menjadi 7 kelompok: zinc gluconate in carrier solution, carrier solution, saline $(0.9 \% \mathrm{NaCl})$ solution, chlorhexidine, chlorhexidinepzinc gluconate, corticosteroid, dan kontrol (tanpa perlakuan). Luka yang diobati dengan zinc glukonat sembuh dan mengandung jumlah bakteri yang sama seperti luka dengan perawatan topikal lain kecuali kortikosteroid.

Berdasarkan pembahasan maka peneliti menyimpulkan bahwa pemberian zinc dapat mempercepat penyembuhan luka perineum. Rata-rata lama penyembuhan luka perineum pada ibu yang diberikan zinc adalah 5,85 hari (Jamhariyah, 2017) dan 9,13 hari (Martanti et al., 2017). Sedangkan ratarata lama penyembuhan luka perineum pada ibu yang tidak diberikan zinc adalah 7,38 hari (Jamhariyah, 2017). Dalam literature review ini peneliti juga menemukan perlakuan lain dalam mempercepat penyembuhan luka perineum yaitu pemberian vitamin $\mathrm{C}$. Rata-rata lama penyembuhan luka perineum pada ibu yang diberikan vitamin C adalah 8,15 hari (Martanti et al., 2017).

Untuk memperkuat justifikasi bahwa zinc dapat mempercepat penyembuhan luka, peneliti juga membahas penelitian lain yang tidak spesifik membahas luka perineum. Penelitian Sakae et al., (2013) menyebutkan rata-rata peningkatan kesembuhan ulkus pada kelompok Zinc Complex $(1,8)$ lebih baik dibandingkan kelompok kontrol $(0,8)$. Penyembuhan luka pada kelompok zinc sebesar 10,38 $\mathrm{mm}$ lebih rendah dibandingkan dengan penyembuhan luka pada kelompok PRP sebesar 13,13 mm (Abdullah, Atasoy and Omer, 2019).

Penelitian $\mathrm{Xu}$ et al., (2017) menunjukkan rata-rata hari penyembuhan luka untuk PIL-Qa-C1 dan PIL-Im-C4 Tikus yang diberi perlakuan $\mathrm{Zn}$ adalah $14.15 \pm 1.68$ dan $13.15 \pm 1.87$ lebih cepat dibandingkan kelompok kontrol yang butuh sekitar $24,33 \pm 1,73$ hari untuk menyembuhkan luka. (lihat Gambar 3C). Penundaan penyembuhan luka di kelompok kontrol terjadi karena infeksi bakteri. Penyembuhan luka yang lebih cepat pada dua kelompok PIL dapat dikaitkan dengan efek bakterisida dari PILQa-C1 dan PILIm-Membran C4-Zn.

Hasil penelitian Anggraeni, Adji \& Sutrisno (2012) menunjukkan Pada kelompok A (tanpa zinc), tiga dari empat tikus $(75 \%)$ menunjukkan epidermis yang sudah tertutup setelah hari ketiga operasi, sedangkan pada dermis masih tampak adanya celah luka yang belum tertutup 
pada seluruh tikus. Sel-sel radang PMN banyak dijumpai pada dermis dan hipodermis di sekitar luka, di samping itu fibroblast like cells yang berbentuk pipih dapat dijumpai di antara sel-sel radang pada dermis di celah luka dan juga di hipodermis. Pada kelompok B (dengan zinc), seluruh tikus menunjukkan epidermis yang sudah menutup (100\%) setelah hari ketiga operasi. Dermis masih menunjukkan adanya celah luka yang belum tertutup pada seluruh tikus. Sel-sel radang PMN dapat ditemukan pada dermis dan hipodermis di sekitar luka, tetapi tidak sebanyak seperti pada kelompok A. Di sekitar tepi luka dan hipodermis dapat dijumpai fibroblast like cells, di samping itu jaringan granulasi yang bersifat fokal juga tampak di daerah hipodermis.

Peneliti menemukan beberapa kekurangan penelitian yang dibahas. Penelitian Aziz, Soemardini \& Nugroho (2016) memiliki keterbatasan dalam jumlah sampel yang relatif sedikit untuk penelitian deskriptif dan cross sectional, jumlah responden penelitian mereka kurang dari 100. Kekurangan penelitian Martanti et al., (2017) adalah tidak melibatkan kelompok kontrol sehingga tidak bisa melihat keefektifan pemberian zinc pada penyembuhan luka jika dibandingkan kelompok yang tidak mendapatkan terapi. Kekurangan penelitian Jamhariyah (2017) adalah tidak melakukan pretes, sehingga tidak bisa dipastikan persamaan kondisi awal luka perineum antara kelompok kontrol dan kelompok eksperimen. Kekurangan penelitian Sakae et al., (2013), Abdullah, Atasoy \& Omer (2019), Sazegar et al., (2011)Xu et al., (2017), Anggraeni, Adji \& Sutrisno, (2012) serta Kaufman et al., (2014) terutama dalam konteks literature review ini adalah tidak spesifik membahas luka perineum.

Smeltzer (2014) menyebutkan bahwa penyembuhan luka perineum salah satunya dapat dipengaruhi oleh nutrisi. Asupan nutrisi, termasuk total kalori, protein, dan nutrisi mikro sangat mempengaruhi penyembuhan luka (Johnson, Ziegler \& Touger-Decker, 2019). Zinc merupakan salah satu nutrisi mikro penting dalam penyembuhan luka yang berperan sebagai kofaktor dalam sistem enzimatik, yaitu zinc-dependent matrix metalloproteinases, yang dapat meningkatkan pembersihan jaringan mati dan migrasi keratinosit. Zinc mencegah apoptosis epitel dengan cara melindungi terhadap reactive oxygen species dan toksin bakteri melalui aktivitas antioksidan dari cysteine-rich metallothioneins. Pemberian zinc mempercepat menutupnya seluruh lapisan epidermis dan sebagian dermis berkaitan dengan fungsi zinc dalam mempercepat reepitelisasi, proliferasi fibroblast dan sintesis kolagen Lin et al., (2018). Efek anti-inflamasi dari zinc dan meningkatnya level zinc dalam darah menunjukkan bahwa zinc dapat melakukan penetrasi ke 
jaringan yang lebih dalam dan diabsorbsi ke dalam sirkulasi darah (Prasad, 2014).

Batas maksimal konsumsi zinc untuk orang dewasa adalah $40 \mathrm{mg} / \mathrm{hari}$, konsumsi lebih tinggi yang berkepanjangan dapat menyebabkan efek merugikan karena dapat mengganggu absorbsi zat lain sehingga dapat memicu kekurangan zat besi dan tembaga. Kelebihan zinc juga dapat menurunkan absorbsi nutrisi yang berasal dari sumber makanan nabati (Johnson, Ziegler \& Touger-Decker, 2019).

Pemberian zinc dikombinasikan dengan terapi lain seperti madu dan vitamin C juga dapat mempercepat penyembuhan luka. Kombinasi zinc dan madu terbukti lebih baik dalam mempercepat penyembuhan luka dibandingkan dengan zinc saja atau madu saja. Kombinasi zinc dan madu dapat mempercepat reepitelisasi, mengurangi peradangan dan mengurangi pertumbuhan bakteri, namun mekanisme tepat yang digunakan zinc dan madu dalam memberikan efek ini masih belum jelas karena interaksi zinc dan madu dengan banyak enzim sistem dan dengan biomembran sangat komplek (Sazegar et al., 2011).

Kombinasi zinc dan vitamin $\mathrm{C}$ juga dapat mempercepat penyembuhan luka karena di dalam duodenum terjadi interaksi antara vitamin $\mathrm{C}$ dan Zinc yaitu berhubungan dengan perubahan $\mathrm{PH}$ saluran cerna, Perubahan $\mathrm{PH}$ ini terjadi karena sifat vitamin C yang asam sehingga mampu menurunkan $\mathrm{PH}$ lingkungan kemudian derajat ionisasi Zinc sulfat akan menurun sebab Zinc sulfat mempunyai derajat keasaman yang rendah sehingga bentuk tidak terionisasi lebih banyak dan kelarutan dalam lemak menjadi lebih tinggi. Di samping itu Zinc sulfat memiliki sifat amfoter dengan energi potensial yang sangat kecil (daya pengoksidasi sangat kecil) kemudian berinteraksi dengan vitamin $C$ yang memiliki daya mereduksi yang kuat, sehingga mampu meningkatkan absorbsi Zinc melalui perbedaan potensial diantara kedua sisi membran (Maggini, Beveridge \& Suter, 2012). Melihat pentingnya zinc dalam penyembuhan luka, ibu post partum direkomendasikan untuk mendapatkan suplementasi zinc untuk mempercepat penyembuhan luka perineum.

\section{Hubungan penyembuhan luka perineum dengan penurunan skala nyeri}

Persalinan pervaginam sebagian besar mengakibatkan luka perineum yang dapat terjadi karena laserasi spontan maupun episiotomi bahkan karena keduanya. Prawitasari, Yugistyowati \& Sari (2015) menyebutkan faktor-faktor yang menyebabkan terjadinya ruptur perineum antara lain faktor ibu yang terdiri dari paritas, jarak kelahiran, cara meneran yang tidak tepat, dan umur ibu. Faktor janin yang terdiri dari berat badan bayi baru lahir dan presentasi. Faktor 
persalinan pervaginam terdiri dari ekstraksi forceps, ekstraksi vakum, trauma alat dan episiotomi, kemudian faktor penolong persalinan yaitu pimpinan persalinan yang tidak tepat.

Penelitian Francisco et al., (2014) dan Mulati dan Susilowati (2018) menyebutkan sebagian besar ibu yang mengalami luka perineum merasakan nyeri. Hal ini sesuai dengan penjelasan Ardani (2018) bahwa kerusakan jaringan dan teraktivasinya faktor pembekuan menyebabkan pelepasan berbagai substansi vasoaktif, seperti prostaglandin dan histamine yang mengakibatkan stimulasi saraf-saraf nyeri.

Hasil penelitian Francisco et al., (2014) dan dan Mulati dan Susilowati (2018) didukung oleh pendapat Smeltzer (2014) yang menjelaskan munculnya nyeri berkaitan erat dengan reseptor dan adanya rangsangan. Reseptor nyeri tersebar pada kulit dan mukosa dimana reseptor nyeri memberikan respon jika adanya stimulasi atau rangsangan. Luka perineum merupakan salah satu rangsangan mekanis.Nyeri dapat dirasakan jika reseptor nyeri tersebut menginduksi serabut saraf perifer aferen yaitu serabut A-delta dan serabut $C$. Serabut A-delta memiliki myelin, mengimpulskan nyeri dengan cepat, sensasi yang tajam, jelas melokalisasi sumber nyeri dan mendeteksi intensitas nyeri. Serabut C tidak memiliki myelin, berukuran sangat kecil, menyampaikan impuls yang terlokalisasi buruk, visceral dan terus-menerus (Potter et al., 2013).

Ketika serabut $\mathrm{C}$ dan A-delta menyampaikan rangsang dari serabut saraf perifer maka akan melepaskan mediator biokimia yang aktif terhadap respon nyeri, seperti : kalium dan prostaglandin yang keluar jika ada jaringan yang rusak. Transmisi stimulus nyeri berlanjut di sepanjang serabut saraf aferen sampai berakhir di bagian kornu dorsalis medulla spinalis. Didalam kornu dorsalis, neurotransmitter seperti subtansi $P$ dilepaskan sehingga menyebabkan suatu transmisi sinapsis dari saraf 16 perifer ke saraf traktus spinolatamus. Selanjutnya informasi disampaikan dengan cepat ke pusat thalamus (Potter et al., 2013). Setelah informasi sampai thalamus inilah ibu yang mengalami luka perineum dapat merasakan nyeri.

Hasil penelitian Mulati dan Susilowati (2018) menyebutkan tidak ada pengaruh yang signifikan antara derajat robekan perineum dengan skala nyeri perineum ibu nifas dengan $\rho$ value $=0,06$ $(>0,05)$. Hal ini terjadi karena sebagian besar responden pada umur reproduktif sehinga masih memiliki kemampuan yang baik untuk beradaptasi dengan rasa nyeri perineum.

Berbeda dengan penelitian Mulati dan Susilowati (2018), hasil penelitian Francisco et al., (2014) menyebutkan terdapat hubungan antara trauma perineum dengan nyeri. Wanita yang mengalami trauma perineum hampir tiga 
kali lebih mungkin memiliki rasa sakit daripada mereka yang memiliki perineum utuh.

Hasil penelitian Francisco et al., (2014) ini didukung oleh penjelasan Saifuddin (2014) yang menyebutkan bahwa skala nyeri tergantung pada derajat luka perineum yang dialami. Derajat laserasi perineum ringan tidak akan menimbulkan rasa nyeri yang berat karena luka yang terjadi biasanya hanya pada luka laserasi derajat 1 yaitu robekan yang hanya terjadi pada mukosa vagina, fourchet posterior, dan juga kulit perineum.

Sedangkan laserasi perineum akibat episiotomi biasanya akan menimbulkan laserasi derajat 2, 3 bahkan ada yang sampai derajat 4. Pada laserasi derajat 3 dan 4 ini biasanya akan menimbulkan nyeri sedang sampai nyeri berat setelah proses penjahitan (Saifuddin, 2014).

\section{KESIMPULAN}

Zinc mampu mempercepat penyembuhan luka perineum. Namun keefektivannya dalam mempercepat penyembuhan luka masih kurang jika dibandingkan dengan vitamin C. Zinc akan lebih efektif dalam mempercepat penyembuhan luka jika dikombinasikan dengan terapi lain seperti madu dan vitamin C. Zinc aman dikonsumsi oleh manusia dengan batas maksimal $40 \mathrm{mg} /$ hari. Ada hubungan penyembuhan luka perineum dengan penurunan skala nyeri.

Penelitian ini diharapkan menjadi masukan bagi tenaga kesehatan terutama bidan untuk memberikan terapi tablet zinc bagi ibu nifas untuk mempercepat penyembuhan luka perineum.

\section{DAFTAR PUSTAKA}

1. Abdullah, B. J., Atasoy, N. and Omer, A. K. (2019) 'Evaluate the effects of platelet rich plasma (PRP) and zinc oxide ointment on skin wound healing', Annals of Medicine and Surgery, 37, pp. 30-37. doi: https://doi.org/10.1016/j.amsu.2018.1 1.009 .

2. Anggraeni, D., Adji, D. and Sutrisno, B. (2012) 'Identifikasi Leptin pada Kesembuhan Luka Tikus yang Diberi Pakan Lemak Tinggi dan Aplikasi Zinc Topikal', Jurnal Veteriner, 13(4), pp. 395-401. Available at: https://ojs.unud.ac.id/index.php/jvet/ar ticle/download/6031/4509.

3. Ardani, W. A. P. (2018) Efektivitas Tablet Vitamin C untuk Mempercepat Penyembuhan Luka Perineum. Poltekkes Kemenkes Semarang. Available at: http://repository.poltekkessmg.ac.id/index.php?p=show_detail\&i $d=15767 \&$ keywords $=$.

4. Aziz, S. S. D., Soemardini and Nugroho, F. A. (2016) 'Hubungan Tingkat Konsumsi Protein, Zat Besi (Fe) dan Zinc (Zn) dengan Kondisi Penyembuhan Luka Perineum Derajat II pada Ibu Nifas', Majalah Kesehatan FKUB, 3(3), pp. 137-143. Available at:

https://majalahfk.ub.ac.id/index.php/m kfkub/article/view/102/92.

5. Francisco, A. A. et al. (2014) 'Association between perineal trauma and pain in primiparous women', Rev Esc Enferm USP, 48, pp. 39-44. doi: $10.1590 /$ S0080-

623420140000600006 . 
6. Frohlich, J. and Kettle, C. (2015) 'Perineal Care', BMJ Clin Evid, pp. 123. Available at: https://www.ncbi.nlm.nih.gov/pmc/arti cles/PMC4356152/pdf/2015-1401.pdf.

7. Guo, S. and DiPietro, L. A. (2010) 'Factors Affecting Wound Healing', Journal of Dental Research, 89(3), pp. 219-229.

doi: $10.1177 / 0022034509359125$.

8. Handayani and Pujiastuti (2016) Asuhan Holistik Masa Nlfas dan Menyusui. Yogyakarta: Trans Medika.

9. Jamhariyah (2017) 'Pengaruh Suplementasi Zinc terhadap Waktu Penyembuhan Luka Perineum pada Ibu Nifas', Jurnal Kesehatan, 5(2), pp. 94-99. doi: 10.25047/j-kes.v5i2.53.

10. Johnson, S., Ziegler, J. and TougerDecker, R. (2019) 'An EvidenceBased Approach for the Use of Vitamin C, Zinc, and Arginine in the Treatment of Severe Pressure Injuries: A Case of a Patient with Multiple Sclerosis', Support Line, 41(2), pp. 10-20.

11. Kaufman, K. L. et al. (2014) 'Evaluation of the Effects of Topical Zinc Gluconate in Wound Healing', Veterinary Surgery, 43(8), pp. 972982. doi: DOI:10.1111/j.1532950X.2014.12243.X.

12. Lin, P.-H. et al. (2018) 'Zinc in Wound Healing Modulation', Nutrients, 10(16), pp. 1-20. doi: 10.3390/nu10010016.

13. Maggini, S., Beveridge, S. and Suter, M. (2012) 'A Combination of Highdose Vitamin C Plus Zinc for the Common Cold', The Journal of International Medical Research, 40, pp. 28-42. doi: https://doi.org/10.1177\%2F14732300 1204000104.

14. Martanti, L. E. et al. (2017) 'The Effect of Zinc and Vitamin C Additional on Healing Process of Second Degree Perineal Wound in Postpartum', Journal of Medical Science and Clinical Research, 5(9), pp. 2753127535.

doi: https://dx.doi.org/10.18535/jmscr/v5i9. 27.

15. Mulati, T. S. and Susilowati, D. (2018) 'Pengaruh Derajat Robekan Perineum
Terhadap Skala Nyeri Perineum pada Ibu Nifas di Kabupaten Wonogiri', Jurnal Kebidanan Dan Kesehatan Tradisional, 3(1), pp. 51-56. Available at: $\quad$ http://jurnal.poltekkessolo.ac.id/index.php/JKK/article/view/ 376/329.

16. Potter, P. A. et al. (2013) Fundamental of Nursing Eight Edition, Elsevier. doi: 10.1109/ISCA.2016.31.

17. Prasad, A. S. (2014) 'Zinc is an antioxidant and anti-inflammatory agent: its role in human health', Frontiers in Nutrition, 1(14), pp. 1-10. doi: 10.3389/fnut.2014.00014.

18. Prawitasari, E., Yugistyowati, A. and Sari, D. K. (2015) 'Penyebab Terjadinya Ruptur Perineum pada Persalinan Normal di RSUD Muntilan Kabupaten Magelang', Jurnal Ners dan Kebidanan Indonesia, 3(2), pp. 77-81. Available at: http://ejournal.almaata.ac.id/index.php /JNKI/article/view/160.

19. Saifuddin, A. B. (2014) Buku Panduan Praktis Pelayanan Kesehatan Maternal dan Neonatal. Jakarta: Yayasan Bina Pustaka Sarwono Prawirohardjo.

20. Sakae, K. et al. (2013) 'Effects of L-Carnosine and Its Zinc Complex (Polaprezinc) on Pressure Ulcer Healing', Nutrition in Clinical Practice, 28(5), pp. 609-616. doi: https://doi.org/10.1177/088453361349 3333.

21. Sazegar, G. et al. (2011) 'The Effects of Supplemental Zinc and Honey on Wound Healing in Rats', Iranian Journal of Basic Medical Sciences, 14(4), pp. 391-398. Available at: https://www.ncbi.nlm.nih.gov/pmc/arti cles/PMC3586837/pdf//JBMS-14391.pdf.

22. Smeltzer, et al (2014) BRUNNER \& SUDDARTH'S TEXTBOOK of Medical- Surgical Nursing, 11th ed. Philadelpia: Lippincott Williams\&Wilkins, awotter kluwe bussiness., Lippincott Williams \& Wilkins. doi: 10.1017/CBO9781107415324.004.

23. Vivian, N. L. (2015) Asuhan Kebidanan pada Ibu Nifas. Jakarta: Salemba Medika. 
24. Wiknjosastro, H. (2016) IImu Bedah Kebidanan. Jakarta: Yayasan Bina Pustaka Sarwono Prawirohardjo.

25. Xu, Q. et al. (2017) 'Zinc Ion Coordinated Poly(Ionic Liquid) Antimicrobial Membranes for Wound
Healing', ACS Applied Material \& Interface, 9(17), pp. 14656-14664. doi:

https://doi.org/10.1021/acsami.7b016 77. 